\title{
THE IMPLICATIONS OF MEMETICS FOR THE CULTURAL DEFENSE
}

\author{
NEAL A. GORDON \\ INTRODUCTION
}

The cultural defense has been the subject of a great deal of recent scholarship. Much of this analysis has concerned the consequences of the cultural defense, both for defendants and victims. ${ }^{1}$ Scholars differ on what these unintended consequences may be, however, and identify effects ranging from encouraging American ideals ${ }^{2}$ to spreading racism, ${ }^{3}$ to legitimizing violence against women. ${ }^{4} \mathrm{Al}$ though seemingly contradictory, these analyses are warranted as they address a legal strategy that often draws from culturally specific norms concerning marriage and domestic relations. ${ }^{5}$ Because norms are central to every culture, use of the cultural defense potentially has a profound effect on many immigrant communities.

Few commentators focus on the philosophical foundation of the cultural defense and whether it forms an adequate basis for excuse from punishment, however. Retribution often is a primary justifica-

Copyright (c) 2001 by Neal A. Gordon.

1. See generally Doriane Lambelet Coleman, Individualizing Justice Through Multiculturalism: The Liberals' Dilemma, 96 COLUM. L. REV. 1093 (1996) (discussing the effects of the cultural defense on victims); Leti Volpp, (Mis)Identifying Culture: Asian Women and the "Cultural Defense," 17 HARV. WOMEN's L.J. 57 (1994) (objecting to the defense on the grounds that it overlooks the subordination that Asian women face); Michael Fischer, Note, The Human Rights Implications of a "Cultural Defense," 6 S. CAL. INTERDISC. L.J. 663 (1998) (describing the conflict between cultural practices and treasured human rights).

2. Note, The Cultural Defense in the Criminal Law, 99 HARV. L. REV. 1293, 1302 (1986).

3. Coleman, supra note 1, at 1134-35.

4. Nilda Rimonte, A Question of Culture: Cultural Approval of Violence Against Women in the Pacific-Asian Community and the Cultural Defense, 43 STAN. L. REV. 1311, 1315-20 (1991).

5. There is no formal cultural defense. For a brief definition and explication of how the cultural defense can operate, see infra Part I. 
tion for punishment. ${ }^{6}$ The cultural defense concludes that because a defendant acted in a "culturally motivated manner," he is not morally blameworthy and hence should be partially excused. The cultural defense makes use of a common assumption in criminal law: if the defendant cannot control her actions, she generally should not be held responsible for them. ${ }^{8}$

This Note challenges this common assumption in the specific context of the cultural defense. By seeking to exculpate a defendant for culturally influenced behavior, the volitional cultural defense ${ }^{9}$ denies the defendant's ability to resist the compulsions of his culture. I do not argue that the defendant can or should be able to act independently of his cultural background; rather I submit that the cultural defense fails to draw any significant distinctions between defendants and the general populace. Everyone is at the mercy of the ideas he encounters; the cultural defense just arbitrarily defines culture narrowly enough to shut out most of these compulsions. From a moraland hence retributivist-viewpoint, the source of these irresistible impulses should make no difference.

Part I examines the cultural defense in greater detail and delineates its cognitive component (in which a defendant may not recognize a law or fact) from its volitional component (in which a defendant recognizes an action is legally wrong but cannot overcome the cultural impulses to act regardless). This part also attempts the important-but difficult - task of separating a pure cultural defense from the mere use of cultural evidence within an existing defense. Part II presents a new theory of cultural evolution, memetics, ${ }^{10}$ that eliminates any volition free from broadly defined cultural and genetic influences. This theory posits that every person, and hence every action, is the result of influences beyond an individual's control. Part III demonstrates that the volitional cultural defense can make no mean-

6. Alison Dundes Renteln, A Justification of the Cultural Defense as Partial Excuse, $2 \mathrm{~S}$. CAL. REV. L. \& WOMEN's STUd. 437, 442 (1993).

7. Id. at 488.

8. See, e.g., People v. Grant, 360 N.E.2d 809 (Ill. App. Ct. 1977) (reversing defendant's conviction for assault on grounds that he suffered from automatism and that his actions were therefore involuntary).

9. The term is defined and distinguished at infra note 32 and accompanying text.

10. The relationship between memetics and the law has previously been explored in Michael S. Fried, The Evolution of Legal Concepts: The Memetic Perspective, 39 JURIMETRICS J. 291 (1999). Fried examines the evolution of the law in terms of memes, while this Note is more concerned with the philosophical implications of memetics for the criminal law, and the cultural defense in particular. 
ingful distinctions, as everyone is acting under cultural compulsions. This part also investigates the roles of deterrence and rehabilitation in a system largely void of retribution. The Note concludes by employing the memetic perspective to reexamine some of the existing consequentialist analyses of the cultural defense.

\section{The Cultural Defense}

The cultural defense has not been formalized ${ }^{11}$-an attorney cannot walk into a courtroom and plead "the cultural defense." Hence it will not fit neatly into one definition. It has been defined as "a legal strategy that defendants use in attempts to excuse criminal behavior or to mitigate culpability based on a lack of requisite mens rea,"12 "[t]he affirmative presentation of foreign customs as exonerating evidence in criminal cases," 13 and "a defense asserted by immigrants, refugees, and indigenous people based on their customs or customary law." 14 This lack of specificity in the defense leads to its application in a number of diverse cases without a clear statement of what it is trying to prove or disprove. ${ }^{15}$ The problem is further complicated by the frequent confusion of the cultural defense with the use of cultural evidence within existing defenses. As a result, it is particularly worthwhile to attempt to explain how the cultural defense operates and to partition its uses along a major divide.

There are important—and often misunderstood-differences between the cultural defense and the use of cultural evidence. The cultural defense proper operates outside of criminal law's existing mechanisms and attempts to excuse the defendant for admittedly wrong conduct. ${ }^{16}$ A true cultural defense is closely parallel to the insanity defense-both seek to excuse a defendant because he either did not know his actions were wrong or could not control them. ${ }^{17}$ The defendant cannot disprove an element of the crime but seeks to be excused anyway, essentially because he could not help himself. Cul-

11. Volpp, supra note 1 , at 57.

12. $I d$.

13. Coleman, supra note 1 , at 1100.

14. Renteln, supra note 6, at 439.

15. See Nancy S. Kim, The Cultural Defense and the Problem of Cultural Preemption: A Framework for Analysis, 27 N.M. L. REV. 101, 117-21 (1997) (examining various misuses of cultural evidence).

16. See Renteln, supra note 6, at 490-92 (arguing that the cultural defense be used as a partial excuse).

17. Kim, supra note 15 , at 109. 
tural evidence, on the other hand, may fit neatly into the existing criminal law framework. A defendant may use cultural evidence to show, for example, that she suffered extreme emotional disturbance. ${ }^{18}$ If cultural evidence is merely used within the existing framework, it presents no philosophical problem as it functions in the same way as any other type of evidence. The proper use of cultural evidence makes justice more precise without sacrificing analytical rigor.

Arguably, the pure cultural defense has never been used by itself. Because the defense has not been adopted formally, defense attorneys often seek to introduce cultural evidence without explicitly stating the purpose of such evidence. ${ }^{19}$ People $v$. Chen ${ }^{20}$ may be the best example of the cultural defense, however, because the cultural evidence was not used to assert a traditional defense. Chen, upon learning of his wife's marital wanderings, killed her in a vicious attack. ${ }^{21}$ The judge reduced the charge from second degree murder to second degree manslaughter, which only requires "recklessness," "after hearing testimony that Chinese culture condemned adultery.",2 Chen's acts-striking his wife eight times with a claw hammer-were clearly intentional and should have warranted a charge of at least first degree manslaughter under New York law. ${ }^{23}$ The problem is that Chen's attorney did not use cultural evidence to establish recklessness, but rather used it to mitigate the punishment. ${ }^{24}$ This demonstrates a significant interpretative problem in the field: defense attorneys often seek to introduce cultural evidence for whatever it is worth, rather than specifically to negate mens rea or to advance some other established defense. This can make for some interesting logic: Chen "argued simultaneously that his rage was governed by his cultural predispositions to such an extent that he became mentally unstable, and that he purposefully acted his part in a culturally rational traditional practice." ${ }^{25}$ The difficulty lies in how to interpret the use of

18. See People v. Wu, 286 Cal. Rptr. 868, 873 (Cal. Ct. App. 1991) (analyzing the effects on the defendant of cultural taboos about adultery). Technically, Wu argued that her extreme emotional distress rendered her unconscious. Id.

19. See Kim, supra note 15, at 118-19; infra notes 34-40 and accompanying text.

20. No. 87-7774 (N.Y. Sup. Ct. Mar. 21, 1989). For an excellent discussion of Chen, see Doriane Lambelet Coleman, Culture, Cloaked in Mens Rea 2 (2001) (unpublished manuscript, on file with the Duke Law Journal).

21. Coleman, supra note 20, at 3.

22. Kim, supra note 15 , at 120 .

23. Id. at $119-20$.

24. See infra notes $41-43$ and accompanying text.

25. Coleman, supra note 20, at 10. 
the cultural evidence-is it a sloppy attempt to use an existing defense or a veiled attempt to mitigate punishment based on the idea that the defendant is less culpable?

It is additionally helpful to split the cultural defense into cognitive and volitional components. ${ }^{26}$ The cognitive portion refers to cases in which "the individual simply did not believe that his or her actions contravened any laws." ${ }^{27}$ Thus, the cognitive cultural defense would encompass cases of mistake or ignorance of law and mistake of fact. The defendant uses cultural evidence to show that she either did not realize there was a prohibition on her actions or that her actions were different from what is prohibited.

One example is People v. Moua. ${ }^{28}$ This case involved the Laotian custom of "marriage-by-capture," in which, in order to be wed, the female must protest the male's sexual advances to prove herself virtuous and the man strong. ${ }^{29}$ Moua forced a Laotian woman from Fresno City College to engage in sexual intercourse; at trial, he argued that he was simply engaging in the Laotian ritual. ${ }^{30}$ If we interpret Moua's actions to mean that he knew rape was illegal but did not think this was rape, his actions show that cultural influences prevented him from realizing the vital fact. The cognitive cultural defense thus attempts to show that the defendant, while perfectly sane and rational, was incapable of committing an act satisfying all the elements of the crime because cultural differences prevented him from being aware of a necessary fact or law. ${ }^{31}$

\footnotetext{
26. Renteln, supra note 6 , at 439.

27. Id.

28. No. 315972-0 (Cal. Super. Ct. Fresno County Feb. 7, 1985).

29. Coleman, supra note 1 , at 1106.

30. Id. He was ordered to serve 120 days in jail and pay a $\$ 1,000$ fine. Id.

31. Renteln, supra note 6, at 439. It is thus arguable that the cognitive cultural defense is not really a pure cultural defense at all but is rather an example of the permissible use of cultural evidence. For example, Moиa can be interpreted as a simple mistake-of-fact case in which Moua's cultural beliefs prevented him from realizing that his victim was not consenting. This may well be true, as the cognitive cultural defense and the simple use of cultural evidence seem quite similar and neither appear vulnerable to the criticisms leveled by this Note. The Note expresses no opinion whether there is a fully-formed, independent cognitive cultural defense; it concentrates instead on the failings of a volitional cultural defense that excuses actions that cannot be defended by the use of cultural evidence within an existing defense.

Conversely, Моиа may also be interpreted as a volitional cultural defense case. Another Hmong defendant claimed, "In my culture there is no such thing as rape." Minnesota v. Her, 510 N.W.2d 218, 220 (Minn. Ct. App. 1994); see also Note, supra note 2, at 1302 ("[T]he ideology of honor is a fundamental precept to which people look for guidance and around which they structure their social relations."). Moua therefore may have known that the sex was non-
} 
The volitional aspect of the cultural defense stands in sharp contrast. The volitional cultural defense argues in essence that the defendant knows her conduct is legally wrong but, due to cultural influences, cannot refrain from such conduct. ${ }^{32}$ The defendant claims that she is not as culpable as she would be had she not been compelled by cultural forces, and the defense is thus similar to diminished capacity and insanity. Examples include People v. $\mathrm{Chen}^{33}$ and arguably People v. Kimura.

After hearing of her husband's infidelity, Kimura, a JapaneseAmerican woman, walked into the ocean holding her two children. ${ }^{35}$ Her children drowned, but she survived. On trial for murder, she used cultural evidence to argue that she was following the Japanese ritual of oya-ko shinju, or parent-child suicide. ${ }^{36}$ Though cultural evidence was not formally admitted, the prosecutor agreed to a plea bargain for voluntary manslaughter on the grounds that Kimura was "temporarily insane." ${ }^{37}$ The "evidence" not admitted consisted in part of a petition of 25,000 signatures from the Los Angeles Japanese community explaining the ritual of oya-ko shinju. ${ }^{38}$ Kimura was sentenced to "one year in prison (which she had served already) and five years probation; she walked out of the courtroom a free woman."

The Kimura case thus may be viewed as a cloaked cultural defense; Kimura's attorney attempted to reduce her sentence without explicitly defining how the cultural evidence was relevant. The same result in the case might have been obtained if Kimura had simply tried to argue extreme emotional disturbance. This lack of clarity allows the case to be interpreted either as a cultural defense case or a

consensual but proceeded anyway. Perhaps he knew that nonconsensual sex was prohibited but thought it was permissible between two Hmong people. This is all speculation, but it reveals the difficulties with these cases. They are quite unclear on whether the defendant actually thought that intercourse with a protesting girl, often under twelve, was consensual; whether the defendant did not think nonconsensual sex was illegal; or whether the defendant knew the act was illegal in the United States but went ahead anyway because of cultural compulsion. The first two alternatives do seem a bit farfetched, which is perhaps why defense attorneys are often vague in their use of cultural evidence.

32. Renteln, supra note 6 , at 439 ; Fischer, supra note 1 , at 670.

33. No. 87-7774 (N.Y. Sup. Ct. Mar. 21, 1989).

34. No. A-091133 (Cal. Super. Ct. L.A. County Nov. 21, 1985).

35. Taryn F. Goldstein, Comment, Cultural Conflicts in Court: Should the American Criminal Justice System Formally Recognize a "Cultural Defense”?, 99 DICK. L. REV. 141, 147 (1994).

36. Id. at 147-48.

37. Kim, supra note 15 , at 118.

38. Fischer, supra note 1, at 673 .

39. Id. 
use-of-cultural-evidence case. In any event, the case does seem to involve the "misuse" of cultural evidence, as it neither fits within the existing framework nor explicitly attempts to assert a pure cultural defense. $^{40}$

Chen also is problematic. "Chen's lawyer ... claimed that 'the basis for the defense was not that it's acceptable to kill your wife in China. The basis of the defense is the emotional strain based on cultural differences and the state of the defendant's mind." "41 Furthermore, the "notion that Chen lacked free will, that he was, in effect, controlled by the 'voice of the [Chinese] community' that 'will be heard everywhere' was a central theme of Chen's defense." ${ }^{, 2}$ While Chen's defense certainly has some echoes of extreme emotional disturbance, it should have been enough only to reduce the charge to first degree manslaughter, not second degree. ${ }^{43}$ The judge's finding that Chen's wielding of the claw hammer was merely "reckless" must therefore contain elements of excuse based on a volitional cultural defense and not be solely derived from a tidy attempt to demonstrate emotional disturbance.

Both the cognitive and volitional cultural defenses are premised on the notion that sometimes "an individual's behavior is influenced to such a large extent by his or her culture" that he commits an act for reasons beyond his control. ${ }^{44}$ The difference between the cognitive and volitional components of the defense is that, under the cognitive portion, the defendant claims that cultural forces prevented him from realizing a fact, but he otherwise acted of his own free choice. Again, this simply may be a specific use of cultural evidence within the established legal framework. Under the volitional portion, however, the defendant admits he knew his actions were wrong but claims that he could not help himself. The defendant using the cognitive cultural defense claims not to have known better, while the defendant using the volitional prong claims that he did not have any choice.

40. See Kim, supra note 15, at 118-19 (noting that Kimura was excused "because her adherence to oya-ko shinju was used to prove that she was temporarily insane").

41. Id. at 120 (quoting Leslie Gevirtz, Immigrant Gets Probation for Killing Wife, U.P.I., Mar. 31, 1989, available at LEXIS/NEXIS, News Library, UPI File (quoting defense attorney Stewart Orden)).

42. Coleman, supra note 20, at 6 .

43. See supra note 23 and accompanying text.

44. Todd Taylor, Note, The Cultural Defense and Its Irrelevancy in Child Protection Law, 17 B.C. THIRD WORLD L.J. 331, 344 (1997). 
This Note is concerned primarily with the cultural defense as it seeks to excuse the defendant based on notions of a lessened culpability due to the behavior's cultural motivation. It argues that the volitional prong is essentially meaningless in that it fails to distinguish between situations in which a person's actions are freely chosen and those in which they are not. To do this, it is necessary to present a theory of culture that shows that we are all purely products of our culture and our biology, and that our actions must therefore be explained in these terms as well.

\section{The Evolution of Culture}

\section{A. Memetics Explained}

The volitional cultural defense claims that people from foreign cultures should be excused when they are unable to control their actions due to cultural influences and that they therefore are less morally culpable. In doing so, the defense implicitly assumes that people from the domestic culture are freely able to conform their actions to the law. In order for there to be an exception to free choice, it must be the norm. But what if people cannot freely choose their actions in any meaningful moral sense? What if everyone's actions are the result of factors, both cultural and genetic, beyond his or her control?

To show that this may in fact be the case, it is necessary to turn to the theory of memetics. ${ }^{45}$ Technically, a meme is "[a]n element of a culture that may be considered to be passed on by non-genetic means, [especially] imitation"; ${ }^{46}$ more crudely, a meme is an idea. Examples of memes include the chorus of a song, equality, heaven, voting, fashion, and language. The biologist Richard Dawkins proposed memes as units of cultural evolution. ${ }^{47}$ In order for culture to be able to evolve, it must be able to be broken down into units that are able to

45. Actually, all that is necessary is some theory of "mindless" or mechanical cultural evolution. There are many theories of cultural evolution, both mechanical and otherwise. See generally THE EVOLUtion of CULTURE-AN INTERDisciplinARY VieW (Robin Dunbar et al. eds., 1999) (collecting essays from various disciplines about cultural evolution). Memetics is a convenient theory, but it is just that - a theory. Should it be disfavored, some other theory of cultural evolution may well fit the bill.

46. Oxford English Dictionary Online, available at http://dictionary.oed.com/cgi/entry/ 00298365 (last visited Apr. 19, 2001) (defining “meme") (on file with the Duke Law Journal).

47. Richard Dawkins, The Selfish Gene 192 (new ed. 1989) (1976). 
reproduce themselves; a meme thus is a discrete idea that is capable of replicating. ${ }^{48}$

In order to replicate, memes must be capable of being stored and spread. The human mind is the ideal vehicle-it is able to store ideas and reliably reproduce them through language. ${ }^{49}$ Not all memetic replication must be achieved through language as a person may simply observe a good idea and imitate it, ${ }^{50}$ but language greatly increases the speed and breadth of a meme's progress. ${ }^{51}$

Memes are of philosophical and psychological interest because of the process by which they evolve. Meme theory holds that memes evolve in the same manner that plants and animals evolve-by the process of natural selection. ${ }^{52}$ Memes, as their name suggests, are analogous to genes in that both satisfy the evolutionary criteria of variation, replication, and fitness. ${ }^{53}$ While the precise neurological mechanisms of memetic evolution may remain unknown or not exist at all, ${ }^{54}$ the comparison between memes and genes is more than meta-

48. Daniel C. Dennett, Darwin's Dangerous Idea: Evolution And the MEANINGS OF LIFE 344-45 (1995). As ideas are somewhat difficult to isolate into discreet units, there is still some question as to what exactly constitutes a meme. For example, "[i]s Beethoven's Fifth Symphony a meme, or only the first four notes?" SUSAN BLACKMORE, THE MEME MACHINE 53 (1999). They both are memes. The symphony itself is a coherent whole that of course replicates every time it is played. The first four notes, however, are probably the more successful meme. They replicate not only when they are played by a symphony or on the radio, but whenever someone hums them. Except for the musical geniuses of the world, it is difficult to keep the entire symphony in one's head and then hum it aloud. The first four notes may therefore be more prevalent in the public's consciousness than the whole symphony. Some people may be aware of the first four notes without knowing where they came from, but that does not preclude the symphony from being itself a meme. The lack of specificity regarding the definition of a meme does not appear to be a problem for memetics, and it is immaterial for our purposes here whether an idea is broken down into its smallest possible components. See id. at 56 (arguing that all that matters for memetic theory is that a meme is replicated, not whether the meme consists of a few notes or a whole song).

49. See Susan Blackmore, The Power of Memes, SCI. AM., Oct. 2000, at 69-71 (relating how evolution shaped the human brain to be well-suited for language).

50. Memes are not entirely unique to humans; bird songs are good examples of memes in the animal kingdom. See John Tyler Bonner, The Evolution of Culture in Animals 119-20 (1980) (noting that bird songs are the product of both genetic inheritance and cultural assimilation); see also Lee Alan Dugatkin, Animals Imitate, Too, SCI. AM., Oct. 2000, at 67 ("Memes may be older and more fundamental to biological evolution than Blackmore or anyone else has argued to date.").

51. See Blackmore, supra note 49 , at 70 (explaining how sounds-and words in particularhave "high[er] fecundity, fidelity and longevity" than other methods of communication).

52. DENNETT, supra note 48 , at 345.

53. Id. at 343 .

54. It is possible that there are precise memetic analogues to all the genetic mechanisms, such as DNA and codons. $I d$. at 345 . This is highly unlikely and irrelevant for our purposes. 
phorical. Both follow the same mindless process of mutation and selection.

As an example, consider a recent meme: the symbol :) that has permeated e-mail. ${ }^{55}$ As one of many symbols called "emoticons," :) is particularly well-suited to the medium of e-mail; it connotes a playfulness that would be evident in voice communications but is otherwise lost in a world of ASCII characters. As people have received email messages containing :), they have recognized its usefulness and incorporated it into their own messages. :) has proven particularly fit, has replicated at breakneck pace, and is now ubiquitous. Like genes, a meme's fitness is its replicative power; in the case of :), it is a function of the meme's unique appropriateness to the medium. It has replicated so well because it is so good at what it does. And as with genes, there are mutations-:(,;), :0, etc. These mutated memes have all replicated because of their own fitness. And eventually, due to overuse, their cleverness and originality will diminish, and they will gradually disappear.

Some have argued that memetics is Lamarckian. ${ }^{56}$ While Lamarckianism, if true, would perhaps deal a fatal blow to the Darwinian theory of genetic evolution, the charge is not as serious with respect to memetics because "memes are not confined by the rigid structure of DNA." ${ }^{57}$ The lack of stasis that makes defining memes so difficult also enables the theory possibly to be Lamarckian without disproving the theory. ${ }^{58} \mathrm{~A}$ related charge is that memetic mutation is

What is important is that the process of natural selection-selection based on fitness-is the same.

55. The symbol :) is known as an emoticon. An emoticon is a "typewritten picture of a facial expression, used in e-mail and when communicating on the Internet, to indicate emotion." TechDictionary.com, the online computer dictionary, at http://www.techdictionary.com (last visited Apr. 10, 2001). The emoticons used in this Note represent a smile, a frown, a wink, and surprise, respectively. See Techdictionary.com, the online computer dictionary, Smilies-Emoticons, at http://www.techdictionary.com/emoticon.html and http://www.techdictionary.com/ emoticon_cont.html (last visited Apr. 10, 2001).

56. BLACKMORE, supra note 48, at 59. "Lamarckian" refers to Jean-Baptiste Lamarck's refuted theory that acquired physical characteristics can be inherited.

57. Id. at 62 .

58. Dennett demonstrates this point by analogizing to viruses. There is no distinction between a soma and germ line in a virus, so it is impossible to tell whether a change in the appearance of the virus is a phenotypic change or a genotypic change (a mutation). Daniel C. Dennett, Memes: Myths, Misunderstandings and Misgivings, § 2, at http://ase.tufts.edu/cogstud/papers/ MEMEMYTH.FIN.htm (last visited April 10, 2001) (on file with the Duke Law Journal). Like viruses, memes are neither multicellular nor sexual, and hence "the fact that there is no clear way ... of distinguishing mutations from phenotypic acquisitions hardly shows that they are disqualified from a neo-Darwinian treatment." Id. 
directed mutation. This criticism poses no threat because any direction is simply the result of prior memes and therefore still forecloses the possibility of a mind free from the infestation of memes. ${ }^{59}$

To thus dodge the objection is not to concede the point. Dennett explicitly acknowledges directed mutation: "much of the mutation that happens to memes-how much is not clear-is manifestly $d i$ rected mutation." ${ }^{60}$ However, the presence of useful and complex memes should not be construed to mean that they are the only mutations. For instance, the symbol :\$ may have occurred to someone, but it was instantly discarded as meaningless. The same phenomenon occurs with genes - a mutation that produces a nonviable organism will generally die out with that organism. The rate of mutation and survival is just much quicker with memes. The sorting of useful and useless memes may occur at an unobservably fast pace because the fitness landscape is the human mind. As a further example, consider a novice poet trying to find a word that rhymes with "child." The poet may try to find words alphabetically: "dialed," "filed," "piled," etc. and may finally settle on "wild." This does not mean that the poet directed the mutation; it means that "wild" was selected because of its fitness and the others were discarded as useless irrelevancies. ${ }^{61}$

Also, memetic mutations seem to occur very frequently- "[w]e seldom pass on a meme unaltered, it seems, unless we are particularly literal-minded rote learners." ${ }^{\circ 2}$ Each time a meme enters a mind it must compete with all the other memes in it, and every mind is different. Thus, every time a meme enters a mind it enters a new fitness landscape. Different mutations may therefore be successful in each mind because of the different selection pressures. These are admittedly speculations, but they may demonstrate that directed mutation does not have to be the only explanation for the selection of appro-

Being Lamarckian would be a distinct benefit for cultural evolution: the eminent evolutionary biologist Stephen Jay Gould argues that a Lamarckian character is the principal power of cultural evolution. Stephen Jay Gould, Shades of Lamarck, NATURAL HIST., Oct. 1979, at 22, 28. Gould postulates that virtually all advances since the rise of Homo sapiens are due to Lamarckian cultural evolution. Id. Because of the accumulative nature of Lamarckian evolution, it has transformed the planet in a geological eyeblink.

59. See infra notes $46-48$ and accompanying text.

60. DENNETT, supra note 48 , at 355.

61. Perhaps some minds are structured (by genes and previous memes) such that they are able to go through this process so quickly that it is not even noticeable and to find words that are beyond the powers of the novice, such as "beguiled."

62. DENNETT, supra note 48 , at 355 . 
priate memes. Even if it is, however, the direction's own memetic origins will preserve the algorithmic theory of culture.

\section{B. What's That Say About Us?}

The concept of memes is important, because it offers a mechanical explanation of how our actions are chosen: we follow whatever notion is strongest in our minds, and the strength of that notion is a function of fitness. Fitness is defined solely in terms of ability to survive and replicate ${ }^{63}$ therefore the memes that are the strongest and most widespread are the ones that are best at replicating. This view is termed the "meme's-eye perspective." ${ }^{\circ 4}$ It captures the crucial idea that memes, like genes, are inherently selfish. They "care" only about their own survival and benefit and not a whit for that of the host organism. The most widespread memes are not necessarily the most beneficial memes; they are simply the memes that are best at spreading. ${ }^{65}$ Luckily, there seems to be a substantial overlap between memes that are good replicators and memes that are good for us. This is because, in general, we pass on (or others pick up on) memes that help us. This is not, however, a necessary correlation. A meme that is obviously beneficial to us as organisms (say, using a wheel) will be recognized as such and hence spread. A meme that is recognized as harmful generally will have a tough time catching on. It is not impossible, however, as demonstrated by the example of suicide. ${ }^{66}$ Other memes, such as racism, may provide a limited benefit for the individual infected with the meme but be quite dangerous to society as a whole.

Thus, the memes that have become the most widespread and deeply entrenched are simply the best replicators. "[T]he facts about whatever we hold dear-our highest values-are themselves very much a product of the memes that have spread most successfully." ${ }^{67}$

63. Anthony J.F. GRIFFITHS ET AL., AN InTRODUCTION TO GENETIC ANALYSIS 728 (7th ed. 2000) (defining fitness as "a consequence of the relation between the phenotype of the organism and the environment in which the organism lives").

64. DENNETT, supra note 48 , at 362 .

65. Id.

66. Richard Dawkins, The EXTEnded Phenotype: The LONG REACH OF THE Gene 110-11 (1982) ("[A] suicidal meme can spread, as when a dramatic and well-publicized martyrdom inspires others to die for a deeply loved cause, and this in turn inspires others to die, and so on ...."); see also Geoffrey Cowley, Viruses of the Mind: How Odd Ideas Survive, NEwSWEEK, Apr. 14, 1997, at 14 (analyzing the Heaven's Gate cult's mass suicide from the memetic perspective).

67. DENNETT, supra note 48 , at 364-65. 
Our highest values are therefore not necessarily the concepts that are true or even beneficial but the concepts that have spread because of their fitness.

If our highest values are simply the result of the fitness of selfish replicators, where does that leave us? We exist the way we do because we are the best way for genes and memes to propagate themselves. "[M]emes restructure a human mind in order to make it a better habitat for memes," not for the benefit of the person. ${ }^{68}$ Just as genes need to make an organism capable of reproducing in order to sustain themselves, so must memes structure a mind to continue their survival. Dennett captures this idea with a beautifully disturbing slogan: "A scholar is just a library's way of making another library." While this idea is initially unsettling in a distinctly Nietzschean manner, it really is nothing new. Biologically, we exist the way we do because that has been the most effective way of passing on our genes, not because we are the most beautiful or powerful organism possible. While we are the product of genetic (and memetic) mutation, we are not the goal-we are the consequence of competitions for survival, not a holy grail of perfection. ${ }^{70}$ From the gene's- and meme's-eye view, we are a means, not an end.

The mind is thus a vehicle for memes to survive and spread. ${ }^{71}$ It is a nest of memes and is shaped by the memes it encounters. The ideas we encounter mold the way we think and pave the way for the acceptance or rejection of subsequent memes. ${ }^{72}$ A good example is education: by its very nature, the idea of education encourages the exploration and absorption of other ideas. The meme of faith, on the other hand, is designed to disarm memes based on reason and scientific proof. ${ }^{73}$ Memes change the architecture of a mind they enter: a mind that is first infected by the meme of faith will find it difficult to accept the meme of reason; conversely, if the meme of reason is first implanted, the meme of faith will be at a disadvantage. Without the memes of space, time, and Newtonian physics, the meme of relativity

\footnotetext{
68. Id. at 365 .

69. Id. at 346 .

70. Id. at 365 . This is an important and often misunderstood point. The only goals of evolution are survival and reproduction-in our case, high intelligence is simply a means to that end.

71. Or more graphically, "a sort of dungheap in which the larvae of other people's ideas renew themselves, before sending out copies of themselves in an informational diaspora." Id. at 346.

72. Id. at 365 .

73. Id. at 349 .
} 
would not have the same replicative power that it does. The computer is a helpful analogy: without certain ideas or programs (such as an operating system) being introduced, other programs (such as word processing programs or games) would be meaningless.

Under this view, the self is a result of memes acting on the hardware of a brain. "[O]ur selves have been created out of the interplay of memes exploiting and redirecting the machinery Mother Nature has given us." ${ }^{74}$ The particular memes encountered and their effects on the physical brain create what is called a self or person. This idea also is not new, at least in general terms; it merely states that a person is the result of a combination of genetics and upbringing, of nature and nurture.

But can't a person choose among the various memes inhabiting her mind? Dawkins famously-or infamously—ended The Selfish Gene by declaring, "We, alone on earth, can rebel against the tyranny of the selfish replicators." "In an endnote, Dawkins discusses one such example-sexual desire. ${ }^{76} \mathrm{He}$ writes that, although humans have "genes influencing sexual desire" they "have no trouble with curbing their sexual desires when it is socially necessary to do so." ${ }^{, 77}$ In one respect, Dawkins certainly is correct: we can overcome the limitations our genes place on us and curb our desires, and in this we seem to be unique. But we are really only trading one set of shackles for another, if we are inclined to take such a view. The only things that are curbing sexual desire are the well-established memes of social decorum that prohibit gratifying our urges in public. ${ }^{78}$ There is nothing left to overcome our memes: "we" are a product of our memes and genes. "This

74. Id. at 367.

75. DAWKINS, supra note 47 , at 201.

76. Id. at 332 .

77. Id.

78. Dawkins is enigmatically silent about this possibility. He seems to intend the appellation "selfish replicators" to apply both to genes and memes: "We are built as gene machines and cultured as meme machines, but we have the power to turn against our creators." Id. at 201. In the endnote explaining this proposition, however, Dawkins claims "that it is perfectly possible to hold that genes exert a statistical influence on human behaviour while at the same time believing that this influence can be modified, overridden or reversed by other influences." Id. at 331. This explanation merely begs the question of what are the other influences. Memes are ideal candidates to fill the role. He seems to go on to limit his original claim: "We, that is our brains, are separate and independent enough from our genes to rebel against them." Id. at 332. He makes no statement at all whether it is possible to rebel against our memes, and this silence encourages the inference that it is not. 
'we' that transcends not only its genetic creators but also its memetic creators is ... a myth." 79

This theory of cultural evolution by natural selection may be difficult initially to accept, as it reduces our selves to a combination of factors beyond our control. The initial discomfort may be due to the theory's potential to upset long-held beliefs about metaphysical freedom, religion, and creativity. ${ }^{80}$ Or maybe the whole theory is just plain wrong. But the theory does make sense on an intuitive level. ${ }^{81}$ If ideas (including those of restraint and asceticism) do not enter our minds through a process of natural selection, how do they get there? Consider the meme of a catchy tune. ${ }^{82}$ Catchy tunes are by definition evolutionarily fit (catchiness means high replicative power), but they are not necessarily good for us; indeed most are downright annoying. But they get stuck in our minds nonetheless, even if we do not want them there. Thoughts pop into our minds all the time, without us having willed them in, and it is a good thing for art-lovers. Mozart is reputed to have said,

[w]hen I feel well and in a good humor, or when I am taking a drive or walking after a good meal, or in the night when I cannot sleep, thoughts crowd into my mind as easily as you would wish. Whence and how do they come? I do not know and I have nothing to do with $i t^{83}$

Memetics thus purports to explain the riddle of how unbidden thoughts creep into our minds, and this intuitive attractiveness is part of what makes the idea both thrilling and disturbing.

The theory of memes offers a mechanical, algorithmic explanation of cultural evolution. Though the parallels with genetics are not strict, memetics retains the core process of selection based on fitness.

79. DENNETT, supra note 48 , at 366.

80. The alteration or overturning of some of these values need not be disappointing or lead to a sort of nihilism. For example, Dennett shows how the theory may lead to a more satisfying view of creativity. We are now able to view our intellectual creations with pride because they are essential products of the memes we harbor, and we are our memes. (In addition, we hold the memes for liking our memes.) Thus, in a very real sense, our creative products are a part of us. See DENNETT, supra note 48, at 355 (describing how individuals rarely pass memes on unaltered).

81. For one thing, it resolves a question that vexes any theory based on a pure free will, namely, why are there differences in willpower?

82. See DenNETT, supra note 48, at 347 (using the example of a song from the 1950s).

83. Id. at 346. Dennett has expressed some doubt as to whether the quotation was in fact from the composer. $I d$. at 346 n. 4 . 
It is this process, rather than the remaining details, that makes memetics interesting from a philosophical and legal point of view. ${ }^{84}$ This Note now applies the theory of memetics to the cultural defense.

\section{Why the Pure Cultural Defense CAnNot Stand}

\section{A. Theories of Punishment}

The theory of memetics, of cultural evolution by natural selection, has profound consequences for the criminal justice system. This Note is not the place to examine all of these effects, ${ }^{85}$ but it is necessary to observe that, of the traditional justifications for punishment, retribution suffers the harshest blow. As memetics explains all human action in terms of causal factors, memes and genes, there is no room for a will not resulting from these factors. Hence, retribution based on free will cannot stand. ${ }^{86}$ In more general terms, memetics shows that a person's experiences shape his actions to a point where moral blame for failing to overcome these experiences is unfounded. ${ }^{87}$

84. And again, it is the process, the mechanistic view of cultural evolution, that is essential to the argument. Memetics is simply one of the best expressions of that view so far.

85. For example, I do not wish to debate the efficacy of various deterrents but merely wish to shore up the foundation for a system of punishment.

86. This is not necessarily the same thing as eliminating all moral responsibility. There is an evolutionary explanation of how morality arose. See id. at 453-93 (arguing for a more positive approach to a "naturalized" ethics); FRIEDRICH NIETZSCHE, ON THE GENEALOGY OF MORALS 57-96 (Walter Kaufmann trans., Vintage Books 1967) (1887) (describing how humans conditioned themselves into morality). It makes perfect evolutionary sense to form an agreement to conduct a society according to certain rules and to punish those who do not follow those rules. Retribution in this sense is a necessary component of deterrence. This brand of retribution is of a different ilk than traditional ideas of retribution based on moral blameworthiness, which focus on whether the defendant could have done otherwise. See NiETzSCHE, supra, at 63 ("[P]unishment, as requital, evolved quite independently of any presupposition concerning freedom or non-freedom of the will.").

87. It is this idea, I think, that gives Rawls's "veil of ignorance" its intuitive appeal. See JOHN RAWLS, A THEORY OF JUSTICE 11 (rev. ed. 1999) (describing the "veil of ignorance"). Behind the veil of ignorance, a person is not permitted to take into account "his place in society, his class position or social status, nor does any one know his fortune in the distribution of natural assets and abilities, his intelligence, strength, and the like." $I d$. This veiled original position for social contracting is fair because "[t]he arbitrariness of the world must be corrected for by adjusting the circumstances of the initial contractual situation." Id. at 122 . Initial endowments are so important, because they alone determine future positions; in emphasizing their importance Rawls essentially denies a will free from genetic and cultural influence: "Even the willingness to make an effort, to try, and so to be deserving in the ordinary sense is itself dependent upon happy family and social circumstances." Id. at 64 . The original position and veil of ignorance combine to make a fair method of choosing a system of justice, because they eliminate from consideration everything over which a person has no control, including the will. Though 
The volitional cultural defense thus fails to draw the line between who should and should not be excused. The defense assumes that Americans who were raised and educated in the "American culture" have no cultural influences to overcome-that, absent any cognitive or other psychological abnormalities, they will be able to conform their actions to the law. Memetics shows us that this is not the case. While the memes of American law may be reinforced more often for someone raised in America than for an immigrant, it is the individual ideas a person encounters-painted across her genotype-that determine her actions. Justice would have to be truly individual to take into account all these differences, but even if possible, it still would not be moral in nature and hence would not provide any justification for exceptions based on culpability.

Drastically reducing the role of retribution reveals the potential importance of deterrence and rehabilitation. The criminal law delineates conduct that is proscribed and thus identifies the thoughts and acts that are unacceptable to a society. As the law is itself a meme, ${ }^{88}$ enforcement of the law can rewire a person's mind to reflect the accepted bounds of conduct. For example, if a person believes that killing one's adulterous wife is accepted, the law can change the person's mental architecture to one that places the value of a human life above the honor of a faithful wife. Every person is, of course, free to disagree with the law, but in an organized society he must follow the law or accept its consequences. Enforcement of the law informs and reinforces the requirements of the law; it deters future prohibited conduct and rehabilitates those who already have committed crimes. ${ }^{89}$ If the law is enforced uniformly, the resulting message is that society will not tolerate such behavior, and this idea gets incorporated into individuals' value systems. The law cannot contain numerous exceptions and still establish its requirements as memes. Exceptions are themselves memes, and care must be taken so that legal exceptions do not become established norms.

The role of the criminal law is thus similar to that hypothesized in a proto-society by Nietzsche and Dennett, among others. ${ }^{90}$ In the

Rawls did not couch it in such terms, his theory is an excellent example of contemplating a justice system while acknowledging that we are memetic and genetic products.

88. See generally Fried, supra note 10 (postulating that the law evolves as memes do).

89. Kim, supra note 15, at 103-04.

90. See NiETZSCHE, supra note 86, at 57-96 (claiming that for the great part of human history, responsibility for one's actions had no bearing on one's punishment). There are of course many variants to the story, but the basic idea is one of social contract-a hypothetical group of 
hypothetical beginning, the law conditions people to overcome their inherent selfish desires and provides incentives to cooperate with others. As shown by prisoner's dilemma games, cooperation is the efficient but not natural solution. ${ }^{91}$ Only by changing the expected payoffs can society hope to change the outcome of the game. This is the law's role-it reaches the previously unworkable solution by changing the rewards and punishments. The law essentially reduces the payoff for noncooperation to a point where it is rational to cooperate, regardless of what other members of society choose to do. ${ }^{92}$ There is an element of conditioning the present as well, so that the immediate impulse is to obey the law and not to compare outcomes and then decide. This is the rewiring the law accomplishes, not some Orwellian eradication of all non-American values. The law changes the incentives of the game-but not the nature of the game-for all members of society. And the incentives are not changed in exactly the same way for everyone; the precise expected payoffs depend on one's memes and the values one places on different outcomes. The key point is that only by the threat of punishment can the law recondition people into avoiding socially inefficient, selfish strategies, and actual punishment is required in order to make the threat credible. In order to reach the desired behavior, the threatened payoffs must approximate the actual payoffs (or at least appear to do so). Thus, the memetic function of the law is to deter selfish conduct and encourage cooperation. ${ }^{93}$

\section{B. “Culture” Defined Broadly}

Considered from another angle, it is apparent that the cultural defense simply defines "culture" very narrowly. In cases such as

humans agrees to be bound by certain rules in exchange for the benefits such rules provide. What this exposition attempts to demonstrate is that the general rule of law and an ordered society are rational and not moral results (although if morality were divorced from a Kantian-type free will, the two could conceivably be the same).

91. See, e.g., Robert Gibbons, Game Theory fOr Applied Economists 2-3 (1992) (explaining the standard prisoner's dilemma game).

92. I am assuming that each decision to cooperate (i.e., commit a crime or not) is a separate game. In an infinitely-repeated game, cooperation is indeed a viable strategy. $I d$. at 90-92.

93. Note that this view of the law does not condemn selfish, antisocial behavior as evil or morally wrong. Indeed, in the absence of laws, some such conduct may be perfectly rational. The goal of the law is to make it more rational to follow the rules and enjoy the benefits of a well-ordered society. 
People v. Kimura ${ }^{94}$ and People v. Moua, ${ }^{95}$ the defense attempted to introduce evidence of a specific tradition or custom that is accepted in a specific society. These cases limit the defense to a practice that is foreign to America but is accepted elsewhere; they do not try to bring up individual ideas and experiences of a defendant that may not be generally accepted in any society. ${ }^{96}$ This is a bit odd considering the broad definitions of culture that some commentators have submitted: "the abstract values, beliefs, and perceptions of the world that lie behind people's behavior" ${ }^{97}$ and "the body of beliefs, ideas, and ideals held by an ethnic group." ${ }^{98}$ Of course, defining culture so broadly is a large step towards admitting that culture is something different for each person, as ideas and ideals vary widely from person to person, even within the same ethnic group. To be fair, culture is notoriously hard to define, ${ }^{99}$ but the cultural defense seeks to excuse individuals because their actions were based upon their culture. To define culture so narrowly as to include only traditional practices or rituals ignores a vast part of the universe of human causation. Were these the only causes of action, human cultures would be remarkably stagnant. Such a narrow definition of culture also ignores the presence of countercultures and people who leave a culture-what could possibly be influencing the minds of those who resist a society's traditions? Memetics is thus useful because it focuses on all ideas and influences, and not just an ill-defined, static group.

94. No. A-091133 (Cal. Super. Ct. L.A. County Nov. 21, 1985).

95. No. 315972-0 (Cal. Super. Ct. Fresno County Feb. 7, 1985).

96. There is the specter of a "subcultural defense" that would seek to excuse defendants whose beliefs were shaped by membership in a subculture, such as a gang. Renteln, supra note 6, at 497-98. Renteln criticizes the subcultural defense on the grounds that the defendants' "worldview is not radically different from the rest of society... [G]ang members do not believe in witchcraft, coining, or other customs integral to a markedly different conceptual system." Id. at 497. While this may be true in some limited sense, the mental architecture that produces action is influenced by more than belief or disbelief in the supernatural. This is why memetics is so useful. Rather than bickering over which beliefs constitute valid excuses and how radical a worldview must be, memetics acknowledges that all beliefs and worldviews are determinants of action and that therefore everyone has an excuse.

97. Fischer, supra note 1, at 669 (quoting William A. Haviland, AnTHROPOLOGY 277 (5th ed. 1989)).

98. Rimonte, supra note 4, at 1315.

99. Fischer, supra note 1, at 668 (observing that there are "over a hundred separate definitions of culture"). 


\section{Consequences of Memes}

Though the volitional cultural defense lacks a sound philosophical basis, we should be careful when we choose to disallow the cultural defense. It is here that consequentialist arguments become important. While it does not generally seem wise to maintain legal mechanisms that are metaphysically untenable, a blanket prohibition on cultural evidence may lead to some unwanted results. As the consequences of the cultural defense have already been examined in some detail, this Note will look at these consequences through the memetic perspective; it will focus on which memes are encouraged by the allowance or disallowance of the defense.

One of the primary justifications for allowing a cultural defense is that it reflects and encourages multicultural sensitivity. ${ }^{100}$ The valuepluralism that the cultural defense promotes is a necessary component of the American ideals of freedom and liberty. To maintain these ideals, Americans must not "foist[] upon all others a single orthodoxy," but rather accept the beliefs and practices of the various groups that comprise America as a whole. ${ }^{101}$ The amount of value a society places on diversity is, in some sense, a measure of the importance that society places on liberty. ${ }^{102}$ It is difficult for a nation to claim that it is founded upon ideas of freedom, tolerance, and personal liberty and at the same time not accept the values of other groups.

The idea of equality is also encouraged by a pluralistic ideal. In order to treat all citizens equally, a society must not proclaim that only the values held by the majority are valid. "Equality among dif-

100. Note, supra note 2, at 1300 . The author argues that individualization of the law is a key component of our criminal justice system. $I d$. at $1298 \mathrm{nn}$. 28, 29. That seems to be the crucial issue here. If everyone's actions are a result of the ideas and experiences (combined with genetics) that influence him or her, truly individualized justice would acquit everyone. We do not want to blame people for actions they could not control, but we also think it necessary to punish some people. We can have it both ways, if we are just a bit more honest. We could punish people to establish the law's deterrent and rehabilitative memes while not morally blaming anyone.

We should, however, still be aware of the other memes propagated by enforcement of the law. If the law eliminates memes that encourage rape and murder, but in doing so spreads memes of hatred and intolerance, the law should be examined to determine if there is a better way of establishing its rules. Thus this section seeks to briefly examine the different possible memetic effects of allowing or disallowing the cultural defense.

101. Id. at 1301 .

102. Id. There is also an evolutionary benefit to diversity. Each culture is material with which nature can accomplish design work. The fewer cultures there are, the fewer values we tolerate, the less material nature has to work with. DENNETT, supra note 48, at 514. 
ferent ethnic groups ultimately requires that each group respect other groups' rights to be different and that the majority not penalize a minority group just because it is different." ${ }^{, 103}$ Respecting the beliefs and practices, to an extent, of all its citizens is thus necessary for a society that wishes to be serious about the value of equality.

Allowing the cultural defense is thus a good way to propagate the memes of liberty and equality. Encouraging a pluralistic society leads to the idea that all ethnic groups are to be respected and that they are free to retain beliefs that are different from those of the majority. The alternative is "the possibility that repudiation of a cultural defense may send out a broader message that an ethnic group must trade in its cultural values for that of the mainstream if it is to be accepted as an equal by the majority." 104 Disallowance of the cultural defense will spread the meme of value-monism, the idea that only the majority's values are valid. This meme will inhibit the spread of the valued memes of liberty and equality.

The meme of value-monism is particularly dangerous because it facilitates the propagation of the memes of intolerance, xenophobia, and racism. Some minds, because of the implantation of previous memes, are quite willing hosts for such memes. Their proclivities for racial supremacy will cause them to seize upon any evidence that they are indeed superior. The rejection of value-pluralism and the societal ratification of the acceptability of only one set of ideas are just such evidence. If only the majority's values are accepted, those holding contrary values are likely to be looked upon unfavorably.

Despite good intentions, allowing the cultural defense may also promote some rather pernicious memes. Foremost among these is the neglect of victim's rights. This idea may take various forms, among them the notions that the cultural defense legitimizes violence toward women $^{105}$ and that it permits violations of human rights. ${ }^{106}$ As cases

103. Note, supra note 2, at 1301.

104. Id. at 1302 .

105. Coleman, supra note 1 , at 1123 ("[T]he state effectively scraps conventional assault, battery, murder, and abuse analysis" in cases involving "wife abuse, mother-child suicide, or female genital mutilation."); see also Daina C. Chiu, Comment, The Cultural Defense: Beyond Exclusion, Assimilation, and Guilty Liberalism, 82 CALIF. L. REV. 1053, 1101 (1994) ("In many, perhaps all, Asian cultures, the subordination of women is traditional and commonplace. When we privilege the voices of Asian men, who rely on their cultures' traditions of beating and killing their wives to excuse their acts, women are silenced." (citations omitted)).

106. Fischer, supra note 1, at 696-97 (declaring that some actions, such as murder and rape, that violate human rights should not be tolerated in any society). 
such as Chen ${ }^{107}$ Kimura ${ }^{108}$ and Moua $^{109}$ demonstrate, all too often it is women and children who are the targets of violence. Any tolerance of this violence by the judicial system helps spread the meme that victim's rights are not to be taken seriously:

The message is sent that if you are an immigrant, you are not guaranteed the right to choose to escape those aspects of your culture (or those stereotypes about your culture) that collide with the criminal law. The victim in People v. Moua is a perfect example of this point. She was an employee at Fresno State University who, like many other young people her age, had left her community to work in an office on campus. Had her parents not been Laotian, the California penal code would have demanded serious punishment for Moua.... Most frightening in this particular case is the fact that because the court adopted the defendant's view of the victim as a member of an immigrant group (of Laotians) rather than as an individual (who may or may not have accepted that culture), she was deprived of the choice to say "No" to her rapist. ${ }^{110}$

If the cultural defense were accepted, Hmong women would have virtually no protection from rape by Hmong men, regardless of whether the women wished to subscribe to the practice of marriage-bycapture.

As the preceding example demonstrates, nonenforcement of the law when the case involves immigrants is discriminatory. The victim in Mоиа was denied redress solely because of her membership in an ethnic minority. Such selective enforcement of the law can be said to violate the Equal Protection Clause, which applies equally regardless of one's citizenship. ${ }^{111}$ Minorities are denied the equal protection of the laws based on their cultural heritage. From the victims' perspective, it is irrelevant whether the failure to enforce the laws is due to officials" "wish to individualize justice through multiculturalism, or because they just do not care as much about crime among immigrants as they do about crime in the majority community." "Allowing violence toward minorities, even if the goal is to exculpate culturally motivated defendants, may propagate the meme of racism. If crimes

\footnotetext{
107. No. 87-7774 (N.Y. Sup. Ct. Mar. 21, 1989).

108. No. A-091133 (Cal. Super. Ct. L.A. County Nov. 21, 1985).

109. No. 315972-0 (Cal. Super. Ct. Fresno County Feb. 7, 1985).

110. Coleman, supra note 1, at 1137 (citations omitted).

111. Id. at 1134 .

112. Id. at 1135 .
} 
against minorities are not enforced, those crimes may be discounted in the popular psyche with the result that minority victims are given less sympathy and care. ${ }^{113}$

The cultural defense may promote the meme of racism in a different, more paternalistic, way as well. This meme is the result of the idea that ethnic minorities need different laws and hence are legally isolated. ${ }^{114}$ The cultural defense is in this way condescending toward other cultures-it excuses action based on foreign cultures by likening it to insanity. The defense takes the view that other cultures are inferior and barbaric but worthy of preservation. This may lead to a "patronizing and subtly racist hypertolerance that 'respects' vicious and ignorant doctrines when they are propounded by officials of nonEuropean states and religions." 115 Thus, instead of objectively valuing a group's practices, as it arguably would for the majority, the cultural defense ends the inquiry when it is discovered that the action was culturally motivated. Rather than recognizing that a culture is organic and that members of an ethnic group may not agree with all of a culture's traditional practices, the defense isolates cultural groups with a patronizing wink. This isolation may lead in turn to a balkanized law and reinforce the idea that minorities should be treated differently. ${ }^{116}$ Furthermore, the cultural defense explicitly takes race and culture into account in meting out criminal justice, and this "may not be a good thing for a judicial system that is already plagued by a racist and sexist history."

Thus, there is a fine line for the cultural defense between being sympathetic toward ethnic defendants and ignoring the rights of victims. On both sides of the line is the possibility of encouraging the meme of racism. Therefore, if we are to disallow the cultural defense, as I have argued we should if it merely is of a volitional nature, we must do so in a manner that is consistent with our goals, namely spreading the memes of tolerance and protection for all.

Cultural evidence can of course still be used if it fits within the existing framework. There seems to be no major problem with allowing cultural evidence to establish, for example, provocation or ex-

113. Id. at 1135 n.207.

114. Chiu, supra note 105 , at 1098.

115. DENNETT, supra note 48, at 517 n.1.

116. Coleman, supra note 1, at 1098 (noting that a balkanized law "is inconsistent ... with one of the law's most fundamental objectives, the protection of society and all of its members from harm").

117. Id. 
treme emotional disturbance. Although there are some questions as to how objective or subjective a reasonable person standard should be ${ }^{118}$ if a defendant can show that she was provoked, say, because of a strong cultural stigma against adultery, her sentence should be reduced according to the guidelines of provocation. If a defendant lacked the mens rea required for the crime, it should not matter why (except in cases where the defendant is responsible for the lack of mens rea, such as voluntary intoxication). This is fundamentally different from a defense that admits all the elements of the crime but seeks to reduce punishment based on culpability; the use of cultural evidence within the existing framework is not at all discouraged by the application of memetics.

The use of cultural evidence does not appear to be a paper tiger, either. As many of the cases seem to involve extreme anger or shame brought about by unfaithful spouses, the defendants still would be able to make arguments based on provocation and extreme emotional disturbance. A true cultural defense only would be necessary when the defendant could not claim such emotional instability or use another defense.

It also might be worthwhile to explore the possibility of a cognitive cultural defense based on ignorance of the law. Ordinarily ignorance of the law is no excuse; however, there do appear to be some instances where cultural factors seem to have dominated the defendant's perception of what is legal. ${ }^{119}$ There are numerous potential problems, however. First, the law essentially would be applying the laws of other countries to people who may have claimed that they were not familiar with American laws. Second, it is unfair to the victims, who thought they were protected by American laws. Third, excuse based on ignorance of the law does more than simply encourage more ignorance; it defeats the memetic power of the law. All of these are good reasons why ignorance of the law is not a traditional defense, and any attempt to change the status quo should include a explanation of why culturally influenced ignorance is different from other kinds.

118. See, e.g., People v. Goetz, 497 N.E.2d 41, 48 (N.Y. 1986) (finding that the standard of "reasonableness" must "retain an objective element").

119. A good example is Regina v. Adesanya, a case in which a Nigerian mother ritualistically scarred her sons' faces without a clue that such conduct constituted assault in England. Renteln, supra note 6 , at $483-84$. 
The use of the cultural defense in cognitive cases such as ignorance of the law is more philosophically sound than in volitional cases, because the former is not based solely on moral culpability. If a defendant is aware of the law but cannot conform his behavior to it, excusing him would be based on the mistaken assumption that others are able to conform their action to the law willingly. Punishing someone for being ignorant of the law, however, makes a much clearer distinction-that person has not been informed of the law in any manner whereas others have. Punishing that person is effective only to the extent that it reduces ignorance of the law. Thus, while establishing a cognitive cultural defense based on ignorance of the law is more sound than volitional cultural defenses, it still must be compared to the effects on the law meme. And if allowing a defense of ignorance of the law will change the expected payoffs in a way that society finds undesirable, it must be abandoned.

\section{CONCLUSION}

Memetic theory seems to imply that eventually memes that are not fit for a new environment will not be replicated. Thus, the marriage-by-capture meme may eventually die out in a society that views sexual consent as a good. This does not obviate the need for punishment, however. Punishment is an essential component of the environment or fitness landscape. It plays a key role in determining which memes are fit to replicate. Without punishment, we could only say that we would not like certain memes to replicate, but they would still be able to do so dependent on their own fitness. Punishment-in whatever form, from incarceration to disapproval and shunningchanges the fitness of the memes. By and large, memes will not be that catchy if they lead their hosts to prison. ${ }^{120}$ This is the catalytic role of law: it drives out the memes that a society views as harmful.

The memetic perspective essentially dispenses with ideas of retribution and punishment based on freedom of the will. This in turn shows that a pure volitional cultural defense, one that seeks to excuse a defendant merely because he could not overcome his cultural influ-

120. Memes that harm their hosts still can be successful replicators. See supra note 66 and accompanying text. Furthermore, as the web of memes is vast and entangled, it is difficult to say that one meme is solely responsible for an action. The meme of vandalism, for example, should have died out as it provides little benefit and may result in a good deal of harm to its host. The meme has managed to propagate, however, in large part because of other, reinforcing memes such as the desire to rebel and the hatred of authority. 
ences, lacks a sound metaphysical foundation. All action is the result of cultural influence, and, whether we like it or not, all punishment seems to be the result of having had the wrong influences. Thus, memetics properly turns the focus of the law to its deterrent and rehabilitative components instead of vague notions of moral wrongdoing. The power of law to affect memetic fitness, and hence action, should not be undermined by excuses founded upon lessened culpability. 